\title{
Globalisation and the Paradox of Participatory Governance in Southern Africa: The Case of the New South Africa
}

Omano Edigheji*

\begin{abstract}
The aim of this paper is twofold. First, it will explore the tensions and contradictions of participatory governance in the context of globalisation in the new South Africa. Second, the paper will interrogate the links between neo-liberal economic reforms and participatory governance in South Africa. In particular, it will explore the question of whether or not participatory governance is inherently democratic and development enhancing. On the basis of the analysis, the paper will explore an alternative scenario that will be relevant for policy and academic purposes for South Africa and other developing countries.
\end{abstract}

\section{Résumé}

Cet article comporte un double objectif. Tout d'abord, il analyse les tensions et les contradictions de la gouvernance participative dans le contexte de la globalisation, dans la nouvelle Afrique du Sud. Deuxièmement, cette contribution interroge les liens entre les réformes économiques néo-libérales et la gouvernance participative sud-africaine. Ce travail s'intéresse particulièrement à la question de savoir si la gouvernance participative est démocratique par essence et susceptible de promouvoir le développement. Sur la base de cette analyse, l'auteur se propose d'étudier un scénario alternatif qui pourra servir aux politiques publique ainsi qu'au monde académique, en Afrique du Sud et dans les autres pays en développement.

\section{Introduction}

The last two decades of the 20th century were marked by increased pressure on developing countries to embrace and promote consultative decision-making. In fact, international development agencies and academics from across the political spectrum pressured these countries

* Senior Researcher at the Centre for Policy Studies in Johannesburg, South Africa. 
to take the path of participatory governance, while at the same time liberalising their economies as the solutions to their political and economic crisis of authoritarianism, poverty, low growth, and marginalisation in the global political economy. Participatory governance is seen as a means to overcome governmental deficits, reduce information gaps and to build consensus around policy, lead to smoother implementation of state policies, ensure accountability and transparency in governance, as well as to enhance the credibility and sustainability of programmes, and to enhance developing countries' global competitiveness.

The debate on economic liberalisation and participatory governance is thus far being cast in positive terms and by so doing, its contradictory dynamics are being overlooked. This resonates in the new South Africa, where the democratic government is being urged to liberalise the economy and promote participatory governance in order to make the economy globally competitive and to improve the standard of living of South Africans, especially the previously disadvantaged communities. This is at a time when the role of the state as a provider of social insurance is being reduced and it is becoming more responsive to the private sector. At the same time, given South Africa's history of political and economic marginalisation of blacks, there is a need to ensure greater participation of citizens in governance (Edigheji 2003). There is also an expectation that the government would intervene in the economy to reduce social exclusion, meeting its democratic commitments to the electorate (especially blacks) and to reduce income and wealth inequalities along racial lines. The African National Congress (ANC), the ruling party in the post-1994 South Africa, believed that participation of citizens is a key factor in transforming the South African polity, society and economy in the democratic dispensation. Accordingly, it argued that:

No democracy can survive and flourish if the majority of our people remain in poverty, without land, without tangible prospects for a better life. Attacking poverty and deprivation must therefore be the first priority of a democratic government. ...Above all, the people affected must participate in decision-making. Democratisation must begin to transform both the state and civil society. Democracy is not confined to periodic elections. It is, rather, an active process enabling everyone to contribute to the reconstruction and development. 
The ANC and South Africans cannot be faulted for anchoring the developmental path of the post-apartheid period on participatory and consultative processes. But the crucial questions that remain unanswered are what should be the economic plank for participatory governance to be developmental and to be inclusive and growth enhancing? Or can it be taken for granted that every economic model will lead to equitable growth? Given that the democratic government's economic policy is based on economic liberalism, along the dominant paradigm and logic of global orthodoxy, we need to ask ourselves whether participatory governance and economic liberalism are compatible. Will they lead to democratic governance and inclusive development in order to overcome the legacies of inequities and pervasive poverty of the apartheid dispensation? To put the question differently, what are the inherent conflicts between neo-liberal economic reforms and participatory governance that the government is simultaneously pursuing?

The aim of this paper is twofold. First, it will explore the tensions and contradictions of participatory governance in the context of globalisation in the new South Africa. Second, the paper will interrogate the links between neo-liberal economic reforms and participatory governance in South Africa. In particular, it will explore the question of whether or not participatory governance is inherently democratic and development enhancing. On the basis of the analysis, the paper will explore an alternative scenario that will be relevant for policy and academic purposes for South Africa and other developing countries.

\section{The Dominant Discourse and Policy Thrust in the Era of Globalisation}

Globalisation, according to former World Bank economist and winner of the Nobel Prize of Economics in 2001, Joseph Stiglitz is the closer integration of countries and peoples of the world which has brought about enormous reduction of costs of transportation and communication, and the breaking down of artificial barriers to the flows of goods, services, capital, knowledge and (to a lesser extent) people across borders' (2002:9). This is coupled with the emergence or reorientation of international institutions such as the World Trade Organisation (WTO), the World Bank and the International Monetary Fund (IMF) 'that have written rules, which mandate or push things like the liberalisation of capital market' (2002:10). As Stiglitz correctly points out, 'The Institutions are dominated not just by the wealthiest countries 
but by commercial and financial interests in those countries, and the policies of the institutions naturally reflect this' (2002:19). Hence, although markets for capital goods produced in the developed world are being liberalised, the same cannot be said of primary goods such as agricultural products by developing countries. As a result, globalisation has unequal benefits. It mainly benefits global capital and the developed world while excluding and marginalising the majority of people in the world, mostly from the developing world from its associated benefits. Indeed, in the latter, poverty, hunger and diseases seem to have been the cost of globalisation. Needless to stress that even in the developed world, a fourth world has emerged with the same characteristics of their counterparts in the developing world. These are mostly underclass and immigrant communities.

In this era of globalisation, governments, across the globe, have become preoccupied with the need to attract foreign investment, to liberalise and deregulate national economies, so as to integrate into the global economy. Consequently, governments are becoming more responsive to the needs of the private sector and becoming a guarantor of capital accumulation. This has been coupled with the privatisation of public goods.

We have been reminded by Cerny (1996) that the key public and constitutional functions of the state are being subordinated to the imperatives of global marketplace - or even being rendered vestigial, as it is increasingly drawn into commodification and marketisation of its activities and structures. This is true of the state in both the developed and the developing world with devastating effects on development, especially on citizens' welfare.

This policy thrust is inspired by the discourse of the New Managerialism that is justified on the grounds of providing more choices for users of public services and exposing service providers to competition through user choices in order to stimulate efficiency in service provision. In simple language, the New Managerialism that underpins public sector reforms across the globe is changing the way citizens and the state as well as its democratic role is conceived. As can be seen from the quotation above, citizens are now conceived as users and consumers. And by that conception, the democratic responsibility of the nation-state is also being changed from improving the welfare of its electorate to that of 'consumers' and 'users', whose ability to gain access to basic services is dependent on ability to pay. Associated with this new discourse and 
policy thrust is the situation that the role of the state as a provider of public goods is being redefined, as is the concept of public goods. Public goods are no longer the provision of goods, namely health, education and welfare services, that improves citizens' welfare, but goods which will meet the needs of the private sector by giving greater attention to its regulatory role - of being night watchman - and the provision of economic infrastructure to enhance the competitiveness of local and national economies.

Hence, 'user fees' has entered the lexicon of states' relationship with citizens. In effect there are conflicting imperatives for democratic practices versus managerial efficiency, and the desire for an effective social welfare safety net versus the need for budgetary responsibility (Kronnenfield and Vike 2002). This new policy shift is increasing poverty as people, especially the lower class, who are unable to pay marketbased prices, have their access to basic social services cut off. As noted above, the activities of the state have become marketized and commodified as part of the new policy thrust. The marketisation of government functions and the consequent commodification of basic services is having adverse effects on citizens, especially the poor.

Concomitantly, national political elites are losing power and control over policy processes and policy outcomes to both domestic and international bureaucratic elites. The latter are gaining much more influence over the policy direction, from agenda setting to implementation. Paradoxically, this shift in power balance runs against the grain of democratic governance, democratic accountability and transparency as more and more policies are undertaken by civil servants without democratic control and in secrecy, a point which is often overlooked by proponents of participatory governance and economic liberalism. Indeed the autonomy of the state in Africa, like most of the developing world, is under attack by the policy of economic liberalisation with the emphasis on a minimalist state and the introduction of new managerialism. In the context of new managerialism, the bureaucratic elites not only rule but they also reign with important implications for democratic governance and accountability. Important policies are now driven and formulated by unaccountable bureaucratic elites, and at times with minimum inputs from, and against, the electoral mandate of governments, with important adverse implications for democratic governance and accountability. 
National parliaments are at the receiving end of this unfolding drama. They are either bypassed or made to rubber-stamp economic policies on which they have little or no input. Thus policy informed by the Washington consensus, which is dominant in the current global conjuncture, has resulted in the usurpation of powers and roles of domestic political elites over national policy-making by both unaccountable domestic and international bureaucratic elites. The latter, in most cases, have exercised considerable power over socio-economic policies. For example, it is not surprising to see World Bank and IMF officials being located at National Finance Ministries and Central Banks. These officials not only vet and veto national macro-economic policies, at times they are involved in the drafting of economic documents that are in accord with the Washington Consensus. These international institutions also use other mechanisms to influence domestic bureaucratic elites, and in the process, national economic policies. These include, among other means, sponsorship of domestic elites to international conferences where they are inundated with the policy pills of the Washington consensus. And because of these supports, the domestic bureaucratic elite tends to become unaccountable to the national political elites. In other words, bureaucratic accountability, a central tenet of democratic governance, is being undermined by the Washington Consensusinformed policy. Also, through development aid, bureaucrats in these international agencies, including the UNDP, exercise considerable leverage over national development agendas that undermine democratic governance.

As pointed out earlier, development agencies, however, continue to romanticise the virtue of citizens' involvement or participation in governance and development. Against this background, democratic governance is seen as a panacea to developing countries' development problems. The UN Secretary General, Kofi Annan, a leading advocate of democratic development in Africa, argues that '... equitable, sustainable development is predicated on transparent, accountable governance. Good governance and sustainable development are indivisible; the former provides the foundation for the latter'. Developing countries such as South Africa are therefore urged to embrace democratic governance as a necessary condition for sustainable development. The United Nations Development Programme (UNDP) in particular has been playing a leading role in promoting democratic governance on the continent, placing emphasis on accountability and transparency in areas such 
as the legislative and the judicial branches of government, civil society organisations in their advocacy and monitoring roles; public and private management, the electoral process, decentralisation and other mechanisms of enhanced participation.

The main argument is that there is a need to give citizens, especially at the local level, greater influence over decisions that affect them. Such influence will help to bring people's knowledge of distinctive local conditions to bear on the implementation of projects. Their participation, it is believed, will make development more sustainable because people will feel more inclined to maintain and possibly contribute funds, time and labour to projects over which they have had some say (Manor 2002). Also, the argument is that citizens' participation will give greater credibility to development policies and policy outcomes. Indeed, citizens' ownership of development is used as a justification for this emphasis on participation. This zeal for people's participation has seen the rise of 'users' committees as policy-networks for interaction between the local state and 'users'. Recall that the concept is that of users and not citizens. The main distinction being that the latter confers some inalienable rights accompanied by civic obligations. In contrast, being a user does not confer such rights. It is constructed around economic transactions with monetary values attached to the relationship.

\section{Governance in South Africa in the Context of Globalisation}

Most countries in the Southern African region embarked on both political and economic liberalisation in the last two decades of the 20th century. South Africa was the last to achieve procedural democracy following the demise of apartheid. Against the theoretical paradigm and dominant policy path set out above, this paper examines their implication for South Africa since the multi-party, non-racial, democratic elections in 1994. Although unique in some ways, developments in South Africa somewhat mirror the dominant trends of political and economic liberalisation in the region - hence this focus in the paper.

This focus is important given that the democratic dispensation in South Africa, as noted above, is confronted with the challenges of promoting democratic governance, equitable development and undoing the legacies of racial and gender inequalities, overcoming past conflicts and reintegrating the economy into the global order. With respect to 
promoting participatory governance, the post-1994 government has set up an array of participatory structures at all levels of governance from the local to the national levels. These include statutory structures such as the National Economic Development and Labour Council (Nedlac); the five Presidential Working Groups, sectoral bargaining councils, and the Integrated Development Plans (IDP) at the local government level. These structures involve a range of stakeholders including trade unions, business organisations, women's organisations, youth associations, the organisations of people with disabilities, co-operatives, etc. With respect to economic policy, the government has predicated its economic reform on market fundamentalism that is dominated by economic citizenship - multinational corporations which move capital, technology and goods across borders. Although the post-1994 period has witnessed some gains, in general terms, this has not been done in a manner that fundamentally alters the nature of poverty. Hence former President Nelson Mandela lamented that poverty remains the main scourge in present day South Africa (cited in Umsebenzi, May 2003).

Mhone and Edigheji (2003) point out that the post-1994 South Africa has witnessed the consolidation, in practice, of the supremacy of the interests of the dominant class in South Africa, who, given the history of the country, happen to be predominantly the white business class. Although the new South Africa has been marked by the mushrooming of consultative and consensus-seeking structures, such structures have further entrenched the interests of this class while those of the previously disadvantaged communities continue to be marginalised. This is evident by the fact that wealth and income inequalities are increasing, especially among the black community, with few blacks having disproportionately reaped the economic benefits that arose from political liberation. This is like development in other parts of the African continent. This is what Abrahamsen calls exclusionary democracies:

Although democracy may, at least initially, have expanded the room for political expression, particularly in terms of a more critical press and opportunities for social and industrial protest, the political influence of Africa's newly enfranchised citizens has been highly limited. In particular, demands for socio-economic improvements by the poorer sections of the population have been effectively ruled out a priori. In this sense, these are exclusionary democracies: they allow for political parties and elections but cannot respond to the demands of the majority or incorporate the masses in any meaningful way (Abrahamsen 2000:133-134). 
The observation by Abrahamsen is pertinent in the South African case. For example, the Department of Water and Forestry (DWAF) recognised that the participation and inclusion of previously disadvantaged communities in water resource management processes was crucial in redressing the inequities of the past and in alleviating poverty. Accordingly, the Department established the Catchment Management Agencies (CMAs), also referred to as the Water Management Agencies (WMAs). The evaluation report of three of the CMAs - the WMA 3 Crocodile West-Marico; WMA 11 Umvoti to Umzimkulu; and WMA 17 Olifants-Doorn (Ministry of the Environment and Energy 2002) highlights important problems that are often ignored by proponents of participatory governance.

The report notes the inadequacy of the process in addressing the needs or problems of people from previously disadvantaged communities. Consequently, the WMAs could not effectively deal with the issues of equitable development. Second, it notes that 'Mechanisms for identifying the correct beneficiaries (PDIs) and the mechanisms of consultation that will lead to the incorporation of the needs of the rural poor in the project design are in general not practised'. As the report notes, 'issues of importance to PDIs, especially the rural poor that would contribute to poverty alleviation are frequently excluded as they are regarded as not relevant to the CMA establishment process'. Third, the report points out that there was 'limited effort in the design phase to ensure the establishment and/or development of linkages with existing local (rural) initiatives such as local water committees. The latter, as the report acknowledged, are well represented and active in addressing local issues. Lastly, it was noted that in establishing the WMAs, the issue of assessing the capacities at the local level in order to participate meaningfully in the decision-making processes was not adequately addressed. Like other consultative processes and structures in South Africa, it was also noted that:

Information dissemination between those involved in the forum and the CMA establishment process and those who are not remain weak. Communication between forum or team members is also not taking place effectively. The roles and responsibilities of forum members in general have not been clearly set out. Overall, there was low participation by people from previously disadvantaged communities, especially black women and the rural poor. This was partly due to the fact that they could not afford the transport cost for them to attend meetings of the 
WMAs, which the designer of the project did not recognise as a significant factor that could enhance their participation and the eventual success of the programme.

Due to all of the above, the report noted that 'There is no common understanding of the clarity and consistency of the overall objectives, purpose and result of the participation process'.

Some of the above problems are also manifest in other participatory processes and structures such as NEDLAC. This is because '... those that participate in the policy process have little time to consult with their constituencies on all issues, in spite of the fact that agreements reached at negotiations are expected to be binding on organisations. Of critical importance is that accountability and transparency, central elements of the strength of civil society organisations, are being undermined as a result. Again, on occasion, there is little co-ordination and reporting back by delegations to the various Nedlac processes' (Edigheji 2003:105). Like the WMAs, the participation of women at Nedlac is very low. As a result, gender is not mainstreamed in its activities.

The policy of fiscal restraint adopted by the national government is having dire consequences not only in addressing past racial inequalities but also in promoting democratic governance and citizens' participation in the development process. As McLennan notes, 'the tendency to pass on responsibility for the growing costs of education to local communities was disguised as an attempt to improve management efficiency and democratic participation by extending responsibility and accountability (ownership) to local communities'. But this has the contrary effects of widening 'gaps in education provision to the detriment of poorer communities'. McLennan further notes:

The emphasis on consultation and collaboration enabled privileged stakeholders to re-articulate the discourse of democratic participation to further group interests and channel resources. As a consequence, consultative relationships were characterised by high levels of distrust within the state, between provinces and within civil society. Finally, civil society was unevenly organised and privileged interests groups were able to dominate the voices of the excluded. In these contexts, participatory processes tended to favour those groups within the state most able to manipulate the system to achieve their interests. Formal consultative and participative processes based on representation did not guarantee that all interests were considered... As a consequence, policy developed tended to favour the privileged middle class and millions of poor rural children 
were excluded from the processes of education transformation (McLennan 2003:205).

By so doing, the apartheid inequalities in the education system, as in the society in general, are being reproduced and reinforced. Consequently, there has been no significant reduction in income and wealth inequality along racial lines in the new South Africa. In fact the poor in black communities are further being disempowered by the policies emanating from consultative and participatory structures and the resort to the 'new managerialism' and technocratic policy making as the overriding paradigm of governance. This point is highlighted in the WMAs' report earlier referred to, where it is observed that 'In broad terms PDIs and rural communities feel alienated from the process through lack of participating (sic) or being able to participate, and through feeling that their issues are not being addressed' (p.10).

The same is true of the recent agreement of the Growth and Development Summit (GDS) as part of the Nedlac process. In spite of pressure from civil society organisations and the trade unions, HIV/AIDS was not addressed by the summit. This was one factor that could have aborted the GDS. Cosatu's president, Willie Madisha, in his address to the summit, lamented the inability to reach agreement on issues around HIV, which was instead deferred to a separate task team (Madisha 2003). The summit was an effort by the national stakeholders 'to commit themselves to a common vision for promoting rising levels of growth, investment, job creation and people-centred development'. But overall, business interests predominated while making very minimum concessions. In the case of retirement funds for example, "the life insurance industry, government, labour and community organisations committed to work towards investing five percent of their investable income' in unspecified 'appropriate financial instruments'. The trade unions in particular were demanding more than ten percent of pension funds be invested in job creating initiatives. But, as we can see from the above, business did not yield to this demand and remains a source of dissatisfaction for the unions. Although the rhetoric in the GDS agreement tended to be progressive, the actual challenge is whether or not the parties to the agreements will fulfil their comments. As I have noted elsewhere, the South African social partners, especially business, are known for not meeting their commitments. In some instances business has worked against agreements that it perceived not to advance its interest. Its continued opposition to labour laws and affirmative action laws and policies are illus- 
trative of this point (Edigheji 2003). Perhaps this is what the Cosatu president, Willie Madisha, had in mind at the GDS when he observed that 'As always at Nedlac, it is easy to talk, hard that action follows the talk'. The unfortunate thing is that there are no effective mechanisms to monitor the implementation of Nedlac agreements, like most participatory structures in South Africa. It is therefore not surprising that the GDS agreement contained similar contents to the 2000 and 2001 Nedlac annual summit agreements (Nedlac 2000 and 2001). Since the almost three years these annual summit agreements were signed, no significant movement has been made toward their implementation. Indeed, the Council has been unable to come up with a work programme towards the implementation of the aforementioned annual summit agreements. Whether the same fate will befall the GDS agreement is yet to be seen.

In general, participatory structures and technocracy have therefore become a means to legitimatise the interests of the dominant groups in society while marginalising the poor and at the same time fostering a sense of disempowerment among them. Similarly, technocracy undermines democratic control over public policy thereby also reducing its legitimacy as public participation, parliamentary debates or other consultative mechanisms are sidestepped. This method of policy formulation and implementation, according to Mkandawire (1999:123) 'is carried out completely oblivious of the demands of good governance and long-term economic development. Indeed, policies are often introduced in isolation from the considerations of political stability or the legitimacy of the authority of elected bodies'.

Mkandawire's observation provides a more profound understanding of the development crisis in South Africa, like the rest of the continent. In the past, scholars such as Herbst (1999) tended to explain the inability of African states to deliver basic services to their citizens as a result of resource constraints. But this seems only part of the answer. A more profound understanding of the issue in the continent is poverty of a developmental vision by African political elites and a complete surrender of their developmental role to the market - hence their citizens are conceived as users rather than citizens with rights and obligations. In this conception, they accept the liberal discourse of participatory governance, and by so doing shift participation from something that is built around citizenship to users with an emphasis on consumption and markets as the effective agents of service provision. In this way, 
they turn citizens into passive economic entities whose access to basic social and physical services and infrastructure is based on ability to pay. Hassen (2003) has highlighted other negative consequences of the shift from citizenship to clients or users to democratic governance:

\begin{abstract}
Managerialism transforms citizens in demobilising ways... Managerialism, furthermore, transforms a collective (citizens) into a singular entity (client). In so doing, the ability of communities to intervene on specific issues is made more difficult, for their treatment by the public service is not as collective but as individual clients... The interaction between the government and its clients is largely seen as transactional. A wider conceptualisation of citizens as active participants in delivery is absent (Hassen 2003:135).
\end{abstract}

This conceptualisation also tends to redefine politics, as politics is conceived in terms of struggle over distribution of wealth rather than the creation of common wealth. Furthermore, it replaces citizen democracy by consumer democracy as citizens are reduced to consumers, clients and users with government services being commodified. The consequence of these policies is the fostering of competition among citizens, leading to conflict rather than cooperation, and more political apathy and disengagement from public affairs than participation, a fact that is ignored by proponents of economic liberalism and participatory governance.

These developments are leading to the displacement of ordinary citizens' participation by the dominance of career politicians and public sector managers. If one uses procedural democracy to judge participation of South Africans, they would have scored highly as evident from the 1999 election with over 80 percent of registered voters turning up for the general election. But this would be an inappropriate measurement. This because there is nowhere in the world where major socioeconomic decisions are formulated or implemented through regular elections - such policy decisions are made in the period between elections in institutional structures within the state or those composed of representatives of the state-capital-civil society. These are the arenas where the contestation over the policy direction largely takes place, although on occasion, especially in the developed world, referenda are conducted to decide on major policy-decisions. Therefore elections do not ultimately decide the outcome of competition for policies and power. As has been poignantly argued by Peter Evans : 
it has become increasingly clear that holding regular elections and maintaining at least nominal protection for civil rights is not sufficient to generate public discussion that has real bearing on the weighting of the developmental goals or the allocation of collective resources (Evans 2002:15)

Therefore, judging the degree of South Africans' participation should be based on their involvement in participatory and consultative decision-making bodies including parliament. In this respect, the findings of Houston et al (1999) are illustrative of the level of citizens' disengagement from public affairs. They report that ' 91.3 percent of respondents never asked a member of the national legislature for assistance, 90 percent never attended public hearings of the national legislature, and 89.4 percent never made enquiries at parliamentary constituency offices' (Houston et al 1999:157). If we are to use these figures as an indicator, they show that there is a low citizen participation in public affairs. And as I have noted elsewhere in the case of Nedlac, besides government, the other social partners in the Council represent only a small fraction of their constituencies, with the membership of the three union federations constituting only 35 percent of the formally employed and business representation accounting for about 30 percent of the total businesses in the country (Edigheji 2003). Taken together, we can conclude that there is low citizen participation in shaping public policy, leaving the political elite and the predominately white business elite to dominate in the process and their interests to prevail. Even in parliamentary budgetary process that has been marked by an increase in civil society participation, Warren Krafchik concluded that 'Formal inputs within the budget process do not sufficiently reflect the growing interests of civil society in budget-related issues' (Krafchik 1999:93) making range of CSOs to conclude that parliament is not an effective vehicle to influence the budget.

The shift from citizenships to users, consumers or clients also has major implications for South Africans and the socio-economic development of the country. Citizenship confers some inalienable rights on the individuals and communities, which were denied to black people by the apartheid government. These rights were restored by the new constitution. However, the adoption of an economic model that emphasises users, consumers and clients, and so-called alternative models of service delivery such as public-private partnerships - which is another word for commercialisation of basic services - that emphasise financial 
sustainability through cost recovery for all services is stripping mostly poor South Africans of these rights, with adverse consequence for sustainable human development and economic growth. The shift from citizenship to users and consumers has the potential to disrupt individual plans and diminish the value of years of work. The result is that it is creating uncertainty and diminishing the capacity of South Africans, especially blacks, to save and make long-term investments that could have become the engine of economic growth in the new dispensation. This is coupled with the fact that poor South Africans are being denied productive economic assets and basic infrastructure. Hence South Africa has experienced a low level of investment and a sluggish economic growth rate. Most South African poor people, owing to the legacy of apartheid, have no access to the means of sustainable livelihoods and are unable to afford basic necessities.

A trend that is consequently emerging in the new South Africa is that 'in the face of gross inequalities and relative under-development, economic liberalism has tended to compromise substantive democracy'. The manner in which the government formulated its major economic policy to date, the Growth Employment and Redistribution Programme (GEAR), is illustrative. The government unilaterally formulated the GEAR policy without consultation with domestic stakeholders, including the Congress of the South African Trade Union (COSATU), an alliance partner of the ruling party, the ANC. By so doing, it circumvented democratic processes and structures including the Nedlac, a national statutory body set up to facilitate dialogue and consensus seeking between government, organised business and trade unions, and civil society organisations. Although the Nedlac Act did not make it compulsory for government to take its macro-economic policy through a consensus process, by unilaterally imposing it and proclaiming its 'fundamentals as non-negotiable', the basis was laid for similar unilateralism by other social and economic interests, and the consequent conflicts that emanate from such actions. The overall effects of these is that in the post-1994 South Africa, according to Mhone and Edigheji:

... consultation, cooperation, consensus seeking and compromises which are essential elements of governance are being replaced by nominal consultation, unilateralism and conflicts. And even when consultations takes place, they serve primarily as information sharing mechanisms rather than for social partners to make meaningful input and influence the policy agenda and outcome. These important policies to integrate the 
domestic economy into the global economy are thus being ruled out of the purview and ambit of consultative and consensus seeking structures. Where consultation takes place around micro-economic issues, the macro environment of economic stabilisation is thus taken as given, and not subject to discussion or consultation. By foreclosing debates on such important political economy issues government is undermining a key tenet of governance (2003:353).

Indeed, GEAR undermines the foundation of participatory governance both by its contents and the manner in which it was formulated and announced. As I have noted elsewhere, GEAR marked a fundamental shift from people-driven to technocratic-driven, with the marginalisation of civil society organisations in the policy process and the predominance of interests of market agents, both local and global, in policy objectives (Edigheji 2003:93). It is therefore not surprising that the predominately white private sector has embraced the government economic policy. In contrast, the black community, especially the trade unions and other civil society organisations that represent the poor and the marginalised, continue to oppose it. What is clear from this is that economic liberalism symbolised by GEAR is leading to a realignment of class forces in South Africa. While the ANC continues to proclaim itself an organisation of the poor and remains in formal alliance with COSATU and the South African Communist Party (SACP), the government seems to be advancing the interests of capital with which it is has an informal alliance. This situation explains the dominance of the interest of business in the national agenda. This once again highlights the disjuncture between the ANC in government and the ANC outside government, with the former not only exercising greater leverage over the development agenda but also driving and defining it. This includes the restructuring of the public service. By so doing, the bureaucrat elites are reconfiguring the state in the new South Africa into a minimalist state along the line of the dominant ideology of the Washington Consensus.

Also, consultative processes are now confined to discussing sectoral and micro-policies whose scope and parameters are conditioned by the objectives of GEAR, a product of a non-consultative process. The implication of this is that consultative processes have limited parameters and influence in the democratic South Africa. They cannot discuss issues that will result in inclusive development as that would require revisiting of the GEAR policy, which the government is not prepared to do at this juncture for fear of scaring off investors, both domestic and 
foreign. By such a narrow preoccupation, the government tends to ignore the generally known fact that investment follows growth and not the other way round. Thus, rather than focus on trying to expand domestic savings as a basis to increase domestic investment which will spur the growth of the economy, the government seems preoccupied with trying to attract the elusive foreign investment as a basis for growth. There cannot be participatory governance where certain policies are ruled to be outside the purview of open discussion and other consultative processes. Even in the East Asian developmental states, which proponents of procedural democracy might classify undemocratic, the governments in those countries subjected their main economic policies to consultative processes, although such consultations were mainly between the state and business, which in turn enhanced such policies and their outcomes. The shared growth outcome of these states is a testimony to the importance of participatory governance.

Furthermore, gains in micro-economic and sectoral policies such as the Labour Relations Act, the Employment Equity Act, etc. with the potential to advance broad based development, affirmative action, equality, justice and workers rights are being revised by the negative impacts of GEAR, which emphasises cost recovery, social policy and privatisation and commercialisation of basic services. The result of which is that these policies are leading to job losses. According to Statistics South Africa (2002) unemployment rose from 16 percent in 1995 to over 30 percent in September 2002. In the process inequality is not only deepening but also denying households access to sources of livelihood - and increasing numbers of people and households, mostly poor and black, are being cut off from access to basic necessities of life such as water and electricity. This is despite the fact that the post-1994 period has been marked by extension of electricity for lighting from 64 percent households in October 1995 to 72 percent in October 2000. In the same period households with access to clean water increased from 79 percent to 83 percent, telephones from 25 percent to 35 percent (Statistics South Africa 2000). Because the commercialisation of these services requires that the market determines prices, the same households are being cut off from such services.

Some scholars have projected that in 1998 over 500,000 households had their electricity cut off (Ruiters 2002) and by early 2001 more than 20,000 households per month had their electricity cut off due to their inability to pay (Fiil-Flynn 2001). The increased tariff of basic 
services has placed a major debt burden on households. In certain towns, as reported by Ruiters, 45 percent of inhabitants were in debt regarding municipal services. In the case of housing, while the government has built about two million houses with households living in formal housing rising from 66 percent to 73 percent in the period referred to above, the housing programme is driven by market imperatives and limits the number of poor households that could afford them. Critics of this model such as Pape and McDonald (2002) note that:

The neoliberal model and its cost-recovery component gradually came to dominate both national legislation and local government practice. On one level this undermined many of the gains in infrastructure. For example, while two millions households may have been given access to water between 1994 and 1999, cost recovery measures and bureaucratic inefficiency made many projects inoperable. Peter Wellman estimated in 1999 that at least 50 percent of the water projects were not functioning (Pape and McDonald 2002: 4).

This is in addition to the fact that the government housing scheme seems to have institutionalised the ghettoising of shacks and informal settlements - one of the inhumane legacies of apartheid - in South Africa, given the poor quality of the new public houses. That these houses are also market-driven has resulted in a situation where their developmental potentials are not realised. This is aptly captured by the former National Chairperson of the South African National Civics Association (SANCO), Moses Mayekiso (SANCO 1994) when he observed that 'Urban and rural development have been presided over by state bureaucrats and have been designed to entrench apartheid. It has been developer-driven and often carefully organised to disempower communities. The result is that development has failed'.

\section{Conclusion}

In this paper, I have highlighted the paradoxes of participatory governance and economic liberalism in the new South Africa. While the government genuinely believed that citizens' participation would lead to democratic development, and consequently established a range of participatory structures and processes, the adoption of conventional economic policy that emphasised cost recovery, fiscal restraints and market efficiency is undermining participatory governance and limiting its impact. Participatory structures are reinforcing the interests of the elite. And, given the apartheid legacy of race and class, it is the rich, 
who are mostly white, and the new black bourgeoisie, who are reaping the benefits of political liberalisation and participatory mechanisms. The latter have created spaces of inclusion and exclusion but with the general effect of disempowerment for the majority of the South African populace who are included to the extent that they do on occasion participate in consultative structures. Therefore an inclusive-exclusive nexus has emerged, and is pervasive in the current dispensation in South Africa.

Against the preceding background, South Africa's developmental future requires a different economic policy premise. Participatory governance should be predicated on an economic model that will unleash the vast resources of South African society. In this respect, providing access to economic assets for the majority of the people is a sine qua non to sustainable development and the consolidation of democratic governance. This requires shared growth, that is growth whose fruits are shared by all. Central components of this approach include the decommodification of basic services, and the provision of social safety nets in terms of access to income opportunities and productive economic assets and activities.

\section{References}

Cerny, P. G, 1996, 'What Next for the State', in Kofman, E. and Youngs, G. (eds.), Globalisation: Theory and Practice, London: Pinter.

Edigheji, O, 2003, 'State-society Relations in Post-apartheid South Africa: The Challenges of Globalisation in Co-operative Governance', in Mhone, G. and Edigheji, O., Governance in the New South Africa: The Challenges of Globalisation, Cape Town: University of Cape Town Press.

Evans, P, 2002, 'Beyond Institutional Monocropping: Institutions, Capabilities, and Deliberative Development’. http://sociology.berkeley.edu/faculty/evans/ Institutional_Monocropping.pdf.

Department of Water Affairs and Forestry, 2002, 'Evaluation of the involvement of Previously Disadvantaged Individuals in public participation processes leading to the establishment of a CMA in the three WMAs of DWAF/DANCED IWRM Project: Summary of Findings', April.

Fiil-Flynn, M. 2001, 'The Electricity Crisis in Soweto', Occasional Paper 4, Municipal Services Project. Johannesburg: University of the Witwatersrand.

Hassen, E, 2003, 'The Power Behind the Desk: Democracy, Collective Bargaining and the Public Service in South Africa', in Mhone, G. and Edigheji, O. (eds.), Governance in the New South Africa: The Challenges of Globalisation, Cape Town: University of Cape Town Press. 
Herbst, J., 1999, 'The Role of Citizenship Laws in Multiethnic Societies: Evidence from Africa', in R. Joseph (ed.) State, Conflict and Democracy in Africa, London: Lynne Rienner Publishers.

Houston, G., Liebenberg, I., and Dichaba, W., 1999, 'The social dynamics of public participation in legislative processes in South Africa', in G. Houston (ed.) Public Participation in democratic governance in South Africa, Pretoria: Human Sciences Research Council.

Kronenfeld, D. B and Vike, H., 2002, 'Collective Representations and Social Praxis: Local Politics in the Norwegian Welfare State', Journal of Royal Anthropology Institute, 8, 621-643.

Krafchik, W., 1999, 'Participation of civil society and the legislature in the formulation of the budget', in G. Houston, G (ed.), Public Participation in Democratic Governance in South Africa, Pretori:, Human Sciences Research Council.

McLennan, A., 2003, 'Decentralisation and its Impact on Service Delivery in Education in Post-apartheid South Africa', in Mhone, G. and Edigheji, O. (eds.) Governance in the New South Africa: The Challenges of Globalisation, Cape Town: University of Cape Town Press.

Mhone, G and Edigheji, O., 2003, 'Towards Developmentalism and Democratic Governance in South Africa', in Mhone, G. and Edigheji, O. (eds.) Governance in the New South Africa: The Challenges of Globalisation, Cape Town: University of Cape Town Press.

Madisha, W., 2003, Speech for Organised Labour at Nedlac Summit. 27. September.http://www.nedlac.org.za/docs/pr/2003/prpr0927c.html.

Mkandawire, T., 1999, 'Crisis Management and the Making of "Choiceless Democracies", in Joseph, R. (ed.) State, Conflict and Democracy in Africa, London, Lynne Rienner Publishers.

Nedlac, 2000, Annual summit agreement.

Nedlac, 2001, Annual summit agreement.

Nedlac, 2003, 'Growth and Development Summit Agreement', 7 June.

Pape, J. and McDonald, D.A., 2002,'Introduction', in Pape, J. and McDonald, D.A., Cost Recovery and the Crisis of Service Delivery in South Africa, Pretoria: HSRC Press.

SANCO, 1994, 'Making People-Driven Development Work', Report of the Commission on Development Finance, Johannesburg: SANCO.

Statistics South Africa, 2000, Earnings and Spending in South Africa: Selected findings and Comparisons from income and expenditure Surveys of October 1995 and October 2000, Pretoria.

Statistics South Africa, 2002, Labour Force Survey, Pretoria, September.

Stiglitz, J., 2002, Globalisation and its Discontents, Victoria: Penguin Books.

Ruiters, G., 2002, 'Debt, Disconnection and Privatisation: The Case of Fort Beaufort, Queenstown and Stutterheim', in Pape, J. and McDonald, D.A., Cost Recovery and the Crisis of Service Delivery in South Africa, Pretoria: HSRC Press.

Umsebenzi, Vol. 6 Number 5.

UNDP. www.undp.org. 